\title{
UTILIZATION OF THE SHERMAN ACT AND THE PRICE EMERGENCY
}

\author{
Fowler HamiltoN*
}

\section{r. The Role of the Antitrust Laws in the Present Emergency}

The antitrust laws are playing an important role during the present emergency. They constitute the traditional instrumentality for removing restraints on the production and distribution of goods. Their enforcement is a most potent weapon for dealing with the anti-productive practices and the anti-productive outlook of some of those who control large productive facilities and to whom the Government necessarily must appeal in the first instance to produce war supplies.

Just before the present war started, three fourths of all the contracts for war supplies had been let to 56 corporations. ${ }^{1}$ A small cluster of powerful corporations dominated the industrial picture. Such concentration of control by employers natIrally evoked large labor organizations similarly controlled. The country must turn to this group of corporations and organizations to supply war needs. The relatively small number of people who control these large corporations and organizations are not unpatriotic, but it is naturally difficult for them to desert the traditional goals of restricted production and high prices. As corporate managers they fear the impact of expanded production upon rigged markets when the war is over.

Although the Sherman Act has helped to save this country from the kind of atrophied industrial feudalism that existed in France, the cartel point of view still has many adherents here. The classic analysis of that point of view and its consequences for war production have been described in a well-known passage from The Economist:2

* B.A., 1931, University of Missouri; B.A. in Juris., 1933, B.C.L., 1934, Oxford University. Member of the Missouri Bar. Special Assistant to the Attorney General; Chief of the National Defense Section of the Antitrust Division, U. S. Department of Justice; and Chief of the War Frauds Unit, U. S. Department of Justice, a unit handling war fraud matters arising from the Antitrust and Criminal Divisions. Contributor to legal periodicals, including the symposium on "The Sherman Antitrust Act and Its Enforcement" (Winter, 1940) 7 Law and Contemprorary Problems.

The views expressed in this article are those of the writer and not necessarily of the Department of Justice.

${ }^{I}$ In OPM Public Statement, July 26, r94I, it was said: "Fifty-six corporations having defense supply contracts with the War and Navy Departments have contracted for almost three-fourths of the total dollar volume of such contracts, according to a compilation made by the Bureau of Rescarch and Statistics, Office of Production Management. The balance of one-fourth of the total volume of defense supply contracts was divided among several thousand contractors."

${ }^{2}$ x 39 The Econonist, June 15, x940, p. 1033. 
But there is another set of ideas, just as false and as enervating, which has not been abandoned, partly because the proofs of its failure, though decisive, are not publicly apparent. This is the set of ideas that has been the dominant economic philosophy of the Conservative Party in the past nine years, the set of notions that sees its ideal of an economic system in an orderly organization of industries, each ruled feudally from above by the business firms already established in it, linked in associations and confederations and, at the top, meeting on terms of sovereign equality such other Estates of the Realm as the Bank of England and the Government. Each British industry, faithful to the prescription, has spent the decade in delimiting its fief, in organizing its baronial courts, in securing and entrenching its holdings and in administering the legal powers of selfgovernment conferred on it by a tolerant State. This is the order of ideas that has transformed the trade association from a body of doubtful legality, a conspiracy in restraint of trade, into a favoured instrumentality of the State. . . . It is the order of ideas . . . that turned "high profits and low turnover" into the dominant slogan of British business; that raised the level of British costs to the highest in the world. It is a set of ideas that is admirable for obtaining security, "orderly development" and remunerative profits for those already established in the industry-at the cost of an irreducible body of general unemployment. It is emphatically not a set of ideas that can be expected to yield the maximum of production, or to give the country wealth in peace and strength in war.

Nevertheless, when the war broke out and it became obvious to all but the purblind that maximum production had become the one object that superseded all others, this antiproductive system was carried to its highest point. The noble army of controllers was recruited from organized industry; the rings, from being tolerated, became endowed with all the power of the State. The result has been what could have been, and was, predicted - not so much an unfair advantage to certain private pockets as a sluggish tempo of advance and a low limit to what was considered possible. British industry, by and large, has, until recent weeks, been making the maximum effort compatible with no disturbance to its customs now or to its profit-making capacity hereafter. There is no accusation of unpatriotism in this; on the contrary, businessmen, placed in an impossible position of divided loyalties and contradictory intentions, have done their best. But the result has been what we see-a startling inadequacy of production. What was formerly prophecy is now fact. . . . Both in tanks and aircraft-to take only the two outstanding cases-the existing rings have failed to produce the goods and, nine months too late, outsiders have had to be brought in.

It is the fundamental axiom of industrial democracy that private groups cannot be allowed to exercise economic powers over others uncurbed by law. This axiom finds particular application when huge defense contracts necessarily delegate to private groups vast economic power. Before this delegation the control of these large concerns over their smaller competitors was already substantial. Augmented by huge war contracts it becomes almost plenary. Acting in concert or even alone, these great corporations in many cases can control or completely eliminate competition in basic industries. If exercised, this power curtails production either by eliminating competitors or by restricting their output. The antitrust laws are still the principal safeguard against the abuse of power which the war contracts necessarily delegate to the great corporations.

Taxes will protect against profiteering, priorities and allocation orders will secure 
the most efficient utilization of existing supplies, and price ceilings of the kind provided for in the present statute will protect against profiteering and dislocations in distribution of the commodities to which those ceilings are applied. But none of these measures, without vigorous antitrust law enforcement, will protect the independent producers from the growing power of these great concerns.

In recent months antitrust law enforcement has been adapted to war conditions and war needs. At the outset of the defense effort conspiracies to restrict the production of defense materials and cartel arrangements with German concerns were attacked and broken. More recently emphasis has been placed upon defining the limits for legitimate concerted action made necessary by the war and upon stopping conspiracies and practices which curtail production by restricting competition either in war materials or in such basic necessities as food and clothing.

\section{Investigation of Restraints upon War Production}

Over three years ago the Antitrust Division of the Department of Justice undertook its frrst investigation into restraints upon production of strategic materials. It found that the production in this country of beryllium, a metal widely used in Germany to make alloys, had been stifled by the abuse of the patent privilege. ${ }^{3}$ This led to an enquiry into the whole field of strategic materials. Startling restrictions upon the production of some important war supplies were disclosed, and a general investigation was started. It has produced numerous cases and is still underway. Artificial and collusive restrictions of production in such essential commodities as aluminum, ${ }^{4}$ magnesium, ${ }^{5}$ beryllium, ${ }^{6}$ military optical instruments, ${ }^{7}$ tungsten carbide, ${ }^{8}$ machine tools, ${ }^{9}$ nitrogen, ${ }^{10}$ bentonite, ${ }^{11}$ pharmaceuticals, ${ }^{12}$ drugs, ${ }^{13}$ dyes, ${ }^{14}$ and synthetic rubber ${ }^{15}$ were uncovered.

In many cases German influence was discovered in certain vital industries. The

${ }^{3}$ Hearings before Temporary National Economic Committee, Pt. 5, pp. $2011-2158$.

-U. S. v. Aluminum Co. of America, et al., S. D. N. Y.

"U. S. v. Aluminum Co. of America; U. S. v. American Magnesium Co.; U. S. v. Dow Chemical Co., S. D. N. Y., indictment returned, Jan. 30, I94X.

${ }^{\circ}$ See note 3, supra.

"U. S. v. Bausch \& Lomb Optical Co., S. D. N. Y., March Term, 1940, complaint and consent decree filed September 16,1940 .

${ }^{8}$ U. S. v. General Electric Co., et al., S. D. N. Y., indictment returned, Aug. 30, $194^{0 .}$

'U. S. v. Central Dye Casting \& Mfg. Co., N. D. Ill., indictment returned, Jan. 25, 1941; U. S. v. Barber-Colman Company, N. D. Ill., complaint filed, Oct. 7, 1941 .

${ }^{10}$ U. S. v. Allied Chemical \& Dye Corp., S. D. N. Y., indictment returned, Scpt. 1, 1939.

${ }^{11}$ U. S. v. American Colloid Co., S. D. N. Y., indictment returned, Aug. 29, 1940.

${ }^{12}$ U. S. v. Ciba Pharmaceutical Products, Inc., et al., D. N. J., information filed, Dec. 17, 1941; U. S. v. Roche-Organon, Inc., et al., D. N. J., information filed, Dec. 17, 194I; U. S. v. Schering Corporation, et al., D. N. J., information filed, Dec. I7, 1941; U. S. v. Schering Corporation, et al., D. N. J., information filed, Dec. I7, 1941; U. S. v. The Swiss Bank Corporation, D. N. J., complaint and consent decree filed and entered Dec. 17, 194I; U. S. v. Julius Weltzien, et al., D. N. J., information filed Dec. 17, $194 \mathrm{I}$.

${ }^{13}$ U. S. v. Alba Pharmaceutical Co., S. D. N. Y., information filed, Sept. 5, 1941; U. S. v. National Wholesale Druggists' Association, et al., D. N. J., indictment returned, Feb. 6, 1942.

${ }^{14}$ U. S. v. General Aniline \& Film Corp., S. D. N. Y., indictment returned, Dec. 19, 1941.

${ }^{15}$ U. S. v. Standard Oil Co. (N. J.) et al., D. N. J., information, complaint, and consent degree filed, March 25, 1942. 
pattern of its use left no doubt that it was a weapon of economic warfare against the democracies. American concerns motivated only by commercial considerations, had been drawn in many cases long before the outbreak of the present war into cartel arrangements with German concerns selling competing products in the world market. The American concern simply went into the cartel because it seemed like good business to divide world markets, raise prices and restrict production. Under the typical cartel arrangement the American concern secured a monopoly in the American market, the English concern secured a monopoly in the British Empire market, and the German concern secured a monopoly in Germany and in South America, while varying arrangements were made for dividing remaining world markets.

When the British blockade cut off German shipments to South America the Germans were able to supply their South American agencies from sources in this country. As a consequence the Germans retained for a time effective control over South American markets and secured rich ${ }^{16}$ profits from these South American sales. Soon after this pattern of German economic control in this hemisphere was disclosed, it was broken by the freezing of German funds and the blacklisting of Axis agencies in South America by proclamation. ${ }^{17}$

While this investigation of restraint upon production of war supplies has been underway, a general enquiry has been made into price-fixing conspiracies and collusive distribution practices which enhance the price of necessities such as food, meat, drugs and clothing. Forty-six cases have already been instituted in the pending food investigation. These cases relate to alleged combinations to fix prices or otherwise suppress competition in the purchase, distribution or sale of meat, milk, fresh and canned fruits and vegetables, bread, cheese, and other food products. ${ }^{18}$

Antitrust law enforcement is an effective instrument for discovering and dissolving artificial restraints upon the production of goods and is the most effective means for creating competition which alone can overcome the anti-productive attitude of many of those who control the large industrial corporations. It is likewise obvious that in times of national emergency, antitrust law enforcement must be closely geared to the activities of other agencies such as the Office of Price Administration and the War Production Board.

\footnotetext{
${ }^{10}$ See the information, complaint, and consent decree in the case of U. S. v. Schering Corporation, et al., D. N. J., filed, Dec. 17, $194 \mathrm{r}$.

${ }^{17}$ Proclamation of July I7, I941, 6 FED. REG. 3555, setting up a blacklist of South American companies and freezing credits.

${ }^{18}$ U. S. v. Evaporated Milk Ass'n, et al. (milk), N. D. Cal., So. Div., indictment returned, June 3, 1941; U. S. v. Produce Exchange of Los Angeles, et al. (butter), S. D. Cal., Cent. Div., indictment returned, Aug. 5, r94I; U. S. v. Seattle Fish Exchange, Inc., et al. (fish), W. D. Wash., No. Div., indictment returned, May 5, 194I; U. S. v. Sheffield Farrns Co., Inc., et al. (milk), S. D. N. Y., indictment returned, May 5, I941; U. S. v. Armour \& Co., et al. (hogs), W. D. Okla., indictment returned, Oct. 17, I941; U. S. v. Atlantic Commission Co., Inc., et al. (potatoes), E. D. N. C., indictment returned, Dec. 8, I94I; U. S. v. Wilson \& Co., Inc., et al. (meat), N. D. Ill., E. Div., indictment returned, July 3, r941; U.S. v. American Meat Institute, et al. (meat), N.D. Ill., E. Div., indictment returned, June I9, I941; U. S v. Canners League of California, et al. (canning), N. D. Cal., So. Div., indictment returned, June 3 , I94I; U. S. v. Kraft Cheese Co., et al. (cheese), W. D. Wis., indictment returned, July I, I941.
} 


\section{Procedures for the Coordination of Antitrust Enforcement and the Work of the War Production Agencies ${ }^{19}$}

Soon after the defense effort got under way steps were taken to coordinate enforcement of the antitrust laws with action taken by defense agencies to accelerate the production of war material. These measures have two aspects. They provide a means for determining the propriety of collective action required by the emergency and for safeguarding against abuses of power thus created. They also provide for the use of antitrust law enforcement to break illegal practices interfering with the war effort. Since then various procedures have been established to achieve this coordination. But they all rest on the basic policy announced in identical letters which the Attorney General sent on April 29, 194x, to Mr. John Lord O'Brian, General Counsel of the Office of Production Management, and Mr. Leon Henderson, Administrator of the Office of Price Administration and Civilian Supply. ${ }^{20}$ In these letters the Attorney General stated:

\section{... The important points of this policy are:}

Meetings of the industry with the Office of Production Management and the Office of Price Administration and Civilian Supply or their representatives are not illegal. Industrial committees may be formed at the request of the Office of Production Management or the Office of Price Administration and Civilian Supply, to work with representatives of such offices on problems involving defense. There will be nothing unlawful in the industry cooperating in the selection of its representatives or in selecting members for committees, or in the activities of such committees provided they are kept within the scope of this letter.

Questions as to whether there is need for such a committee, and if so, how it shall be chosen, and by whom constituted, shall be the sole responsibility of the Office of Production Management or the Office of Price Administration and Civilian Supply. This Department will not participate in these decisions beyond the suggestion now made that any such committee should be generally representative of the entire industry and satisfactory to the Office of Production Management or the Office of Price Administration and Civilian Supply.

Each industry committee shall confine itself to collecting and analyzing information and making recommendations to the Office of Production Management or the Office of Price Administration and Civilian Supply, and shall not undertake to determine policies for the industry, nor shall it attempt to compel or to coerce any one to comply with any request or order made by a public authority.

All requests for action on the part of any unit of an industry shall be made to such unit by the Office of Production Management or the Office of Price Administration and Civilian Supply and not by the industry committee. That is to say, the function of determining what steps should be taken in the public interest should in each case be exercised by the public authority which may seek the individual or collective advice of the industry itself or by its representatives.

Requests for action within a given field, such as the field of allocation of orders, shall be made only after the general character of the action has been cleared with the Department of Justice. If the general plan is approved, thereafter each request for specific action in carrying out such plan shall be made in writing and shall be approved by the office of

\footnotetext{
10 The abolition of the Office of Production Management and the creation of the War Production Board will apparently make no change in the problems under discussion.

${ }^{20}$ Dep't of Justice Release, April 29, $194 x$.
} 
the General Counsel of the Office of Production Management or the office of the General Counsel of the Office of Price Administration and Civilian Supply, but need not be submitted to the Department of Justice. In the case of any change in the personnel of such offices or if serious practical difficulties arise, this latter arrangement may be revoked upon notice from me.

Acts done in compliance with the specific requests made by the Office of Production Management or the Office of Price Administration and Civilian Supply and approved by their General Counsel in accordance with the procedure described in this letter will not be viewed by the Department of Justice as constituting a violation of the antitrust laws and no prosecutions will be instituted for acts performed in good faith and within the fair intendment of instructions given by the Office of Production Management or the Office of Price Administration and Civilian Supply pursuant to this procedure.

In the case of all plans or procedure, however, the Department reserves complete freedom to institute civil actions to enjoin the continuing of acts or practices found not to be in the public interest and persisted in after notice to desist.

The letter established four important principles governing antitrust law enforcement policy during the emergency: (I) Meetings of businessmen with appropriate Government officials for the purpose merely of discussing action to be taken in connection with war production are not considered a violation of the federal antitrust laws. (2) Government agencies may secure an expression of the views. of the Department of Justice regarding action which they may request businessmen to undertake. (3) All programs must be formulated, put into effect and policed by the Government agency. (4) The Department of Justice reserves complete freedom of action to enjoin the continuation of any plan found not to be in the public interest and persisted in after notice to desist.

The policy and procedures established in Attorney General Jackson's letter were immediately used by the Office of Production Management and the Office of Price Administration. Other defense agencies soon requested that procedures be established for the application of the basic principle to their work. Correspondence between the Attorney General and the Secretary of the Interior ${ }^{21}$ established a procedure under which the Office of Petroleum Coordinator secured the application of this policy to recommendations made by it. This procedure has also been invoked by the Commissioner for Transportation for the National Defense Advisory Counsel, ${ }^{22}$ the War Department, the Navy Department, and defense measures undertaken by that division of the Department of Agriculture which has succeeded to the work formerly done by the Commissioner for Agriculture of the National Defense Advisory Commission.

Under this procedure a variety of matters have been handled. Arrangements have

\footnotetext{
${ }^{21}$ Letter of June 3, 194r, from the Attorney General to the Secretary of the Interior; letter from Secretary Ickes to the Attorney General, dated June $16, x 941$; and the reply of the Attorney General, dated June 18,1941 .

${ }^{22}$ Since the transfer of the functions of this office to the Office of Transportation Coordinator created by the Executive Order of Dec. I8, 194I, 6 FED. REG. 6725, the procedure has been applied to this office. Letter of Feb. 8, 1942, from Joseph B. Eastman, Director of Defense Transportation, to the Attorney Gencral, and the reply of the Attorney General to Mr. Eastman, dated Feb. 12, 1942. For the texts of these letters, see (1942) 9 ICC PrAcr. J. 564-568.
} 
been made to eliminate the use of cork in certain products; to restrict the use of tin; to reduce the production of automobiles; ${ }^{23}$ to reduce the use of metal in certain commodities; to deal with problems in the turbine gear industry; to effect a reduction in the amount of chlorine used in the production of pulp and paper; to effect a simplification of lines; to curtail the production of certain types of sheet and strip steel; to secure cross-licensing of certain patents by members of the aircraft industry; to effect more efficient production of ammonia; to conserve chrome, copper, nickel, steel, raw rubber and mica; to increase the production of titanium oxide pigments; to conserve silk and insure the orderly distribution of available rayon supplies; to increase the production of magnesite brick; to increase the supply of dissolving pulp for the manufacture of explosives; to insure the adequate supplies of waste paper and many other important commodities.

The procedure was somewhat extended, although the basic principle which required a request for action by the Office of Production Management before the program could be approved was retained, in connection with efforts made recently to distribute defense work among a large number of small concerns. By Executive Order of September 4, I94I, ${ }^{24}$ a Division of Contract Distribution under the direction of Mr. Floyd B. Odlum was established in the Office of Production Management. The Executive Order contemplates that where individual concerns are too small to secure defense contracts they will pool their productive facilities so that they can secure either a prime contract or a large subcontract. In a letter addressed to the Attorney General by Mr. John Lord O'Brian, General Counsel of the Office of Production Management, on September 30, I94I, Mr. O'Brian pointed out that,

... the procedure outlined in the Attorney General's letter addressed to me under date of April 29, I94I has worked out efficiently and satisfactorily in the preparation for National Defense. Under the basic principles laid down in that letter, it would seem that no question of violating the anti-trust laws would be presented by conferences held pursuant to the written request of OPM for the purpose of pooling facilities and experience in the fields of production and distribution in order jointly to obtain contracts or subcontracts.

On October 4, r94I, Attorney General Biddle replied that preliminary discussions looking to the formation of defense industry associations, if carried on in good faith, would not be viewed by the Department of Justice as constituting a violation of the antitrust laws if the following conditions were observed:

(x) The discussions will be carried on pursuant to the written request of the Office of Production Management; (2) when a particular plan for collaboration or cooperation is formulated, the plan will be submitted to the Department of Justice in accordance with the procedure outlined in the letter of the Attorney General addressed to you and dated April 29, I94I; and (3) no action will be taken by those participating in the discussions unless the action is strictly within the limits of a plan which has been approved by the Office of Production Management and submitted to the Department of Justice.

\footnotetext{
${ }^{23}$ Reduction of the number of automobiles, of course, was made prior to the promulgation of the action stopping further production of automobiles.

246 FFD. REG. 4623 (rg4r).
} 
The Attorney General also stated:

For this reason, the Department of Justice must necessarily reserve freedom of action, as it did in the letter of the Attorney General addressed to you and dated April 29, I94I, to institute civil actions to enjoin the continuing of discussions and practices which have been found not to be in the public interest and which have been persisted in after notice to desist.

This procedure for the pooling of facilities has been applied both to nation-wide arrangements in a single industry and, more frequently, to regional associations of small manufacturers. The former case is illustrated by the conversion of manufacturers of household washing and ironing machines to the production of war material, the latter by such local defense associations as the Ypsilanti Manufacturers Consolidation for Defense; San Francisco Defense Works, Inc.; Toledo Defense Production Association; Chicago Defense Association, Inc.; Queens Manufacturers Pool; Central New Jersey Pool; Defense Industries of Montpelier, Ohio; St. Louis Pool of Canvas Production Manufacturers; and the Defense Manufacturing Pool, Inc. of Marin, Sonoma, and Napa Counties, California.

The application of the basic antitrust enforcement policy to situations involving the conversion of major civilian industry to the large-scale production of war material was made clear by an exchange of correspondence between the Attorney General and Mr. John Lord O'Brian, General Counsel of the Office of Production Management, on January 2, 1942. Action required by administrative orders based upon statutory power of course raises no questions under the antitrust laws.

Increasing shortages in materials and amplification of the statutory priority and allocation powers have resulted in defense agencies taking more action by formal order and less by informal arrangements which might involve questions under the antitrust laws. Informal arrangements still possess certain advantages. They enable resourceful administrators to explore the fruitful possibilities of cooperative action before resorting to the rigidities of regulations in fields where formal statutory sanctions do not exist or where administration must be delicately attuned to variety and change. Consequently the War Production Board still finds it convenient in many cases to form advisory committees. It does not clear each of these committees with the Department of Justice, because the Attorney General's letter of April 29, x94x, makes it evident that such committees do not themselves constitute a violation of the federal antitrust laws.

At the present time the War Production Board only clears with the Department of Justice the particular activity which it proposes to request each member of the industry to undertake. All committee meetings which are held under this procedure are called by the War Production Board, whose representative presides at such meetings, and complete minutes of the meeting are retained. No group of industry representatives is authorized to meet without the presence of a representative of the Board except in order to comply with the request to furnish that office with informa- 
tion or recommendations, and then only upon the condition that such meetings are confined to the subject matter of the request.

This procedure is now being used by the War Production Board, the Office of Price Administration, ${ }^{25}$ the Army Department, the Navy Department, the Defense Plant Corporation, the Office of Petroleum Coordinator, the Office of Solid Fuels Coordination, the Maritime Commission and the Department of Agriculture. It is capable of application to almost any situation where the public interest requires cooperation between businessmen and a war agency. This arrangement has provided an effective means of coordinating antitrust law enforcement with other aspects of the war effort. Through enforcement of the antitrust laws, artificial restrictions on production of war materials and combinations to raise the prices of necessary commodities are being discovered and defeated. By virtue of this procedure war agencies are able to secure all the advantages that may arise from cooperative rather than coercive action.

Since the completion of the foregoing article, arrangements concerning antitrust litigation have been effected in correspondence between the President, on the one hand, the Attorney General, the Secretaries of War and Navy, and the Assistant Attorney General in charge of the Antitrust Division, on the other hand. ${ }^{20}$ These arrangements affect neither the operation, the validity, nor the need for the procedures outlined in Part 3 above. The new arrangements simply provide for complete coordination with all-out prosecution of the war.

On March 20, 1942, the Attorney General, the Secretaries of War and Navy, and the Assistant Attorney General in charge of the Antitrust Division in a joint letter to the President of the United States stated in part:

\footnotetext{
${ }^{25}$ The provisions of the Emergency Price Control Act, Pub. L. No. 421, 77th Cong., 2d Sess. (1942), which give the Price Administrator power to take action which may directly affect Sherman Act enforcement are $\$ \$ 2(\mathrm{a}), 5$, and $205(\mathrm{~d})$.

Section 2 (a) permits the establishment of maximum prices and provides for the creation of committees to advise the Administrator on price policies. The latter provision raises no question of conflict with antitrust law enforcement because committees of this character have already been established under the procedure described above. The former would eliminate the likelihood of price-fixing conspiracies in cases where the demand for the commodity covered by the price ceiling raised prices of all sellers up to the maximum price. Scope for antitrust enforcement aimed at price-fixing combinations would remain where no maximum prices have been established and where concerted action had been used to fix the prices or bring them up to the maximum. Even where the demand for the commodity forces the price for all sellers up to the maximum, ample scope for illegal combinations to suppress competition in production, in distribution or in terms of sale other than price will no doubt remain.

Section 5 authorizes the Administrator in general terms to enter into voluntary agreements for the establishment of maximum prices, and the Attorney General is to be furnished a copy of cach such agreement or arrangement. The extent to which this will alter existing practice is problematical. The Administrator has already cleared with the Department of Justice numerous situations in which he has individually agreed with handlers of commodities not to exceed price ccilings. Presumably, this section authorizes somewhat more general agreements, and by virtue of $\$ 205(\mathrm{~d})$, the legality of these is confirmed.

Section 205(d) gives immunity from other legal sanctions to persons complying in good faith with the Act or regulations or agreements under it. This provision, in so far as antitrust law enforcement is concerned, simply makes explicit the immunity from antitrust laws which is given to anyone complying with the statutory scheme. The accepted canons of statutory construction would presumably have yiclded the same result.

${ }^{26}$ The texts of the letters appear in N. X. Times, March 29, 1942, $\{1$, p. 33.
} 
Each pending and future Federal court investigation, prosecution or suit under the Anti-Trust Laws will be carefully studied and examined as soon as possible by the Attorney General and the Secretary of War or the Secretary of the Navy, respectively. If the Attorney General and the Secretary of War or the Secretary of the Navy come to the conclusion that the court investigation, prosecution or suit will not seriously interfere with the all-out prosecution of the war the Attorney General will proceed.

If they agree that it will interfere, or if after study and examination they disagree, then, upon receipt of a letter from the Secretary of War or the Secretary of the Navy stating that in his opinion the investigation, suit or prosecution will seriously interfere with the war effort, the Attorney General will abide by that decision and defer his activity in that particular matter, providing, however, that he shall have the right, in such event, to lay all the facts before the President, whose determination, of course, shall be final. In each case the action finally taken will be made public.

The deferment or adjournment of the investigation, suit or prosecution will not, however, mean the exoneration of the individual or corporation, or the discontinuance of the proceeding. As soon as it appears that it will no longer interfere with war production, the Attorney General will proceed.

To make sure that no one escapes by the running of the statute of limitations, we shall request Congress to pass an appropriate extension of the statute.

Under no circumstances will there be any suspension or postponement of prosecution for any actual fraud committed against the government.

On the same day the President replied in part:

I am sure that the Departments of Justice, War and Navy will all cooperate so that the needs of the war will not be hampered by these court investigations, suits or prosecutions, but that at the same time the crisis of war will not be used as a means of avoiding just penalties for any wrongdoing.

In other words, it must be made very clear that the war effort is being impeded. No right-minded person, or any one who is conscious of what is at stake, should use the nation's extremities as an excuse to violate any statute.

Nor, indeed, should there be any deferment or adjournment of any court investigation, prosecution or suit unless, after a study and examination with the Attorney General in each specific case, the Secretary of War or of the Navy is satisfied that the war effort will be jeopardized at this time unless such course is followed.

I note from your memorandum that proper steps will be taken to avoid the running of the statute of limitations in any case; and that under no circumstances will there be any delay in the prosecution of acts involving actual fraud upon the government.

I also heartily approve your intention of making public each determination arrived at by you in accordance with your memorandum. The American people should be informed of each step in their war effort, excepting, of course, any information which may in any way help the enemy in his attempt to destroy us. 